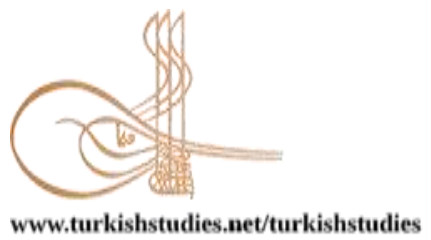

Turkish Studies

www.turkishstudies.net/turkishstudies

eISSN: $1308-2140$

BALKAN
UNIVERSITY

Sponsored by IBU

Research Article / Araștırma Makalesi

\title{
Özel Eğitim Öğretmenliği Öğrencilerinin Koronavirüs (COVID-19) Salgın Sürecinde Uygulama Derslerine İlişkin Deneyimleri
}

\author{
Experiences of the Special Education Teaching Students in the Applied Courses During \\ Coronavirus Disease (COVID-19) Pandemic Process
}

Pelin Piştav Akmeşe* - Nilay Kayhan**

\begin{abstract}
This study aimed to investigate the experiences of the students who continue higher education, specialize in the special education teaching hearing impairment sub-field about the applied courses that are performed through distance education during coronavirus disease (COVID-19) pandemic process, which started in the December of 2019 and is a global pandemic now. The study, designed as qualitative research, was conducted with 9 students in total; 6 students who take the School and Institution Experience in Special Education course and 3 students who take Teaching Practice in Special Education course. The data collected with the semi-structured interview form which was developed specific to the study by the researchers in May of 2020 was obtained via telephone or online due to the pandemic. Ethics committee approval was obtained for the study (03.11.2020; Number: E--804.01-BABBFCF3). NVivo program was used to analyze the data in a detailed and holistic way. As a result of the analysis of the data obtained from the interviews, four main themes which are What process brought, What happened in the process, what coronavirus disease (COVID19) pandemic process taught, Expectations and suggestions were obtained. The students stated that equality of opportunities became prominent in the institutions which meet the criteria of being prepared for education in the digital environment during the COVID-19 pandemic process. Besides, as teacher candidates, they emphasized the lack of technology use in face-to-face courses. They stated that the applied courses can be transferred to the digital environment to some extent as in the face-to-face education, however, the audio-visual systems should be functional for this. They especially suggested that distance education research application centers should be established in the higher education institutions; local administrations should open support centers for accessibility and for the students who have limited opportunities.
\end{abstract}

Structured Abstract: Introduction: The most critical period of development is the early period and preschool years. Quality of the communication of parents and teachers with the students is significant in terms of the language, speech, and social skills of the children. Because the environments in which the children experience rich language inputs, play games, and individual differences are taken into account are highly effective on the

\footnotetext{
* Doç, Dr. Ege Üniversitesi, Eğitim Fakültesi, Özel Eğitim Bölümü

Assoc. Prof. Dr., Ege University, Faculty of Education, Department of Special Education

ORCiD 0000-0001-8269-3899

pelinakmese@gmail.com

** Doç, Dr. Hasan Kalyoncu Üniversitesi, Eğitim Fakültesi, Özel Eğitim Bölümü

Assoc. Prof. Dr., Hasan Kalyoncu University, Faculty of Education, Department of Special Education

ORCiD 0000-0002-0937-8013

nilaykayhan@gmail.com

Cite as/ Atıf: Piștav Akmeșe, P., \& Kayhan, N. (2020). Özel eğitim öğretmenliği öğrencilerinin Koronavirüs (COVID-

19) salgın sürecinde uygulama derslerine ilişkin deneyimleri. Turkish Studies, 15(8), 3669-3688.

https://dx.doi.org/10.7827/TurkishStudies.44410

Received/Geliş: 22 June/Haziran 2020

Accepted/Kabul: 20 December/Aralık 2020

Copyright $\odot$ MDE, Turkey

Checked by plagiarism software

Published/Yaym: 25 December/Aralık 2020

CC BY-NC 4.0
} 
academic, social, and emotional language and communication skills in the following years. However, all these arrangements cannot be limited to the duties of only parents or only teachers. For example, the peers of the child, other personnel who work in the educational environment, support services personnel also have roles and responsibilities in the educational process. One of the special needs that require intervention in the early period is hearing loss and teachers, audiologists, language speech therapists and other experts are as responsible as the families for the infants to reach quality services in the early period. In this context, it has been expected that the personnel who will be responsible for the education, health services of the children with hearing loss receive a quality education; evidence-based practices are carried out in terms of knowledge, skills, and competences.

Another group responsible for the education of the hearing impaired children is the special education teacher candidates in the higher education institutions which train professionals through undergraduate and postgraduate education. Thus, it is important to investigate the opinions of the students who go on their education in the department of special education teaching, will specialize in the hearing field, and accordingly, are practicing in the schools for the deaf. This study aimed to investigate the experiences of the students who continue higher education, specialize in the special education teaching hearing impairment sub-field about the applied courses that are performed through distance education during coronavirus disease (COVID-19) pandemic process, which started in the December of 2019 and is a global pandemic now.

\section{Method}

The study, designed as qualitative research, was conducted with 9 students in total; 6 students who take the School and Institution Experience in Special Education course and 3 students who take Teaching Practice in Special Education course. The data collected with the semi-structured interview form which was developed specific to the study by the researchers in May of 2020 was obtained via telephone or online due to the pandemic. Ethics committee approval was obtained for the study (03.11.2020; Number: E--804.01BABBFCF3). NVivo program was used to analyze the data in a detailed and holistic way. The study is limited to the experiences of the teacher candidates who are in the third of the final year of special education teaching and who will specialize in hearing impairment about the applied courses conducted through distance education during the COVID-19 pandemic process.

\section{Results}

As a result of the analysis of the data obtained from the interviews, four main themes which are What the process brought, what happened in the process, what coronavirus disease (COVID-19) pandemic process taught, expectations and suggestions were obtained. The students stated that equality of opportunities became prominent in the institutions which meet the criteria of being prepared for education in the digital environment during the COVID-19 pandemic process. Besides, as teacher candidates, they emphasized the lack of technology use in face-to-face courses.

They stated that the applied courses can be transferred to the digital environment to some extent as in the face-to-face education, however, the audio-visual systems should be functional for this. They especially suggested that distance education research application centers should be established in the higher education institutions; local administrations should open support centers for accessibility and for the students who have limited opportunities. Another remarkable finding is the opinions about the development of foreign language knowledge as well as the use of information communication technology-based tools to give application experiences in the digital world in a qualified way.

\section{Conclusion}

The teacher training system is a whole. Although the first thing that comes to mind when the teacher training is mentioned in the prevocational training (undergraduate education) of the teacher candidates, the development of knowledge and skills is also provided through on-the-job training when the teachers begin the profession. Thus, the training should be primarily based on the professional needs of the teachers and should be supportive in terms of the knowledge and skills required in this age. When thinking that digital accessibility and technology-based planning becomes prominent in our age, distance education and applications should be frequently used besides face-to-face education. Accordingly, professional on-the-job training should take the current conditions of the teachers into account and be planned with a holistic perception which allows experiencing the skills as well as working together and knowledge. For this purpose, besides written and visual 
materials, safe online supportive web environments can be prepared for the teacher candidates. In order for the teacher candidates to effectively use the content prepared by the Council of Higher Education and Ministry of National Education, local administrations can prepare mobile applications taking the accessibility features of the place into account in the internet and infrastructure services. Web-based online seminars, web conferences in which the teacher candidates meet the teachers and academicians in the profession can be organized. As the graduates have anxiety about the competency and job anxiety about the future, graduates who had previously taken these courses in the pandemic and homeschooling processes can give digital applied education to small groups with the teachers in the profession. Interactive instructional plans can be developed. To support the teacher candidates in terms of knowledge and skills, cooperation with other institutions and people can be suggested.

Keywords: Special education, coronavirus disease, COVID-19, pandemic, distance education.

Öz: Bu çalışmada 2019 yılı Aralık ayında başlayan ve küresel bir salgın olan koronovirüs (Covid-19) salgın sürecinde yükseköğretime devam eden özel eğitim öğretmenliği işitme yetersizliği alt alanında uzmanlaşan öğrencilerin, uzaktan eğitim ile yürütülen uygulama derslerine ilişkin deneyimlerinin incelenmesi amaçlanmıştır. Nitel araştırma desenindeki araştırma, işitme yetersizliği alanında uzmanlaşan Özel Ĕgitimde Okul ve Kurum Deneyimi dersini alan 6 öğrenci ve Özel Ĕ̈itimde Öğretmenlik Uygulaması dersini alan 3 öğrenci olmak üzere toplamda 9 öğrenci ile gerçekleştirilmiştir. 2020 Mayıs ayında yarı yapılandırılmış görüşme tekniğinde çalışmaya özgü geliştirilen görüşme formu ile toplanan veriler, salgın nedeni ile mobil telefon veya online olarak görüşmelerle elde edilmiştir. Çalışma için etik kurul izni alınmıştır (03.11.2020 Sayı:E--804.01-BABBFCF3). Verilerin ayrıntılı ve bütünsel biçimde analiz edilmesi amacıyla NVivo programı kullanılmıştır. Araştırmada yapılan görüşmelerden elde edilelen verilerin analizi sonucunda Sürecin getirdikleri, Süreçte yaşananlar, Koronavirüs (Covid-19) salgın sürecinin ögrettikleri, Beklentiler ve öneriler olmak üzere toplam dört ana temaya ulaşılmıştır. Öğrenciler COVID-19 pandemic process dijital ortamda eğitime hazırlıklı olma ölçütünü karşılayan kurumlarda fırsat eşitliğinin öne çıktığını belirtmişlerdir. Ayrıca öğretmen adayları olarak yüz yüze derslerde teknoloji kullanımının eksikliğini vurgu yapmışlardır. Yüz yüze eğitim gibi uygulama derslerinin de belirli oranda dijital ortama aktarılabileceğini, ancak bunun için sesgörüntü sistemlerinin işlevsel olması gerektiğine ilişkin görüşler belirtmişlerdir. Özellikle yükseköğretim kurumlarında, uzaktan öğretim araştırma uygulama merkezlerinin kurulmasını, erişilebilirlik ve imkanları sınırlı olan öğrenciler için yerel yönetimler tarafından destekleyici merkezler açılmasını önermişlerdir.

Anahtar Kelimeler: Özel eğitim, koronavirüs, Covid-19, küresel salgın, uzaktan eğitim.

\section{Giriş}

Eğitim, her bireyin temel bir hakkı olup, yasal düzenlemelerle güvence altına alınmıştır. Anayasa'da ifade edilen haklar, İnsan Hakları Evrensel Beyannamesi, Çocuk Hakları Sözleşmesi gibi düzenlemeler bu güvenceye örnekler arasında yer almaktadır (MEB, 2020, MEV, 2014:7-2-8; TBMM, 2011; UNICEF, 2020). Gelişimsel farklılıkları veya doğum öncesi, sırası ya da sonrasında oluşabilen bir nedene bağlı özel gereksinimleri olan çocukların da bu temel haktan yararlanmaları esastır (Batu, 2014:10-11; MEB-Özel Eğitim Hizmetleri Yönetmeliği, 2018). Özel gereksinim alanı işitme engelli olan öğrencilerin, okul öncesi dahil zorunlu eğitim kademeleri ile yükseköğretim fırsatlarından yararlanması anayasal bir haktır. Öncelikle dil becerileri olmak üzere diğer gelişim alanlarında etkisini gösteren işitme yetersizliğinde erken tanı ve erken müdahalenin önemi büyüktür. İşitme yetersizliği olan çocukların eğitim süreçlerinin niteliği erken tanı, erken müdahale, aile katılımı, cihazlandırma koşulları ile uygun iletişim becerileriyle destek hizmetlerin sağlanmasına bağlıdır (Piştav Akmeşe, 2018:72; Kirazlı, 2020:12). Ancak tüm bunların temeli, doğru bir değerlendirme ile işitme kaybının erken dönemde belirlenmesidir. Alan yazında Belgin tarafından her yıl yaklaşık olarak 2500 bebeğin işitme kaybı ile doğduğu ifade edilirken (2011:187); işitme engelli çocuklar için yeni doğan taramalarının, erken tanı ve müdahale açısından önemli bir veri olduğuna dikkat çekilmiştir (Piştav Akmeşe, 2020:47). Türkiye'de yeni doğan işitme taraması programı sonuçlarına göre işitme kaybı görülme oranı \%0.2'dir. 2002 yılında Türkiye Cumhuriyeti 
Aile ve Sosyal Politikalar Bakanlı̆̆ı'nın Engelliler Araştırması verilerine göre, toplumda görülen sağırlık oranı \% 0.38 (Bolat ve Genç, 2012) iken Dünya Sağlık Örgütü verileri incelendiğinde (Mart ayı-2020) yeryüzünde 466 milyon işitme engelli bireyin yaşadığı ve bu grubun 34 milyonunu çocukların oluşturduğu ifade edilmiştir (Dünya Sağlık Örgütü, 2020a). Özellikle sosyal ve duygusal etkiler bakımından bireyin içinde yaşadığ 1 topluma katılımını sınırlandıran işitme engeli, soyut kavramların anlaşılmasını zorlaş̧ırmakta, iletişim ve etkileşimde güçlükler yaşanmasına yol açabilmektedir (Dünya Sağlık Örgütü, 2020a; Piştav Akmeşe, 2020:48-49). Alanyazında doğuştan veya sonradan oluşan işitme engelli bireylerin bilişsel, sosyal, duygusal, dil ve iletişim becerileri açısından desteğe gereksinimleri bulunmaktadır. Özellikle erken tanıyı takiben özel eğitimden yararlanmaları ve iletişim, okuryazarlık becerileri açısından konuşmaya dayalı dil ya da işaret dili gibi iletişim yöntemleri ile desteklenmeleri gerekmektedir (Piştav Akmeşe, 2020:53). Çünkü ev ortamındaki dil girdilerinin eksikliği, uzun vadede bilişsel ve dil gelişimi yönünden işitme engeli olan çocuklar için olumsuz bir etki oluşturmaktadır (Göl Güven, 2016). Dolayısıyla işitme engelli bebeklerin ev ortamında ebeveynleri ile kuracakları etkileşimin niteliği, okul çağında da öğretmenleri ve akranları ile etkileşimlerine temel oluşturmaktadır. Dil edinimi bakımından kritik dönemlere dikkat çeken Piştav Akmeşe ve Acarlar (2016:1362) erken çocuklukta ailenin işitme engelli çocuğu ile kuracağ iletişimin önemli olduğunu; Girgin ve Kemaloğlu (2017) ise evde zengin dil girdilerinin sağlanması, çocuğa karşı nitelikli bir dinleme davranışı sergilenmesi gerektiğini belirtmişlerdir. Okul çağı çocuklarının bulundukları sınıf ve sosyal çevrede iletişimlerinin desteklenmesi de en az ev ortamı kadar önemlidir.

Ülkemizde 1950’lerden itibaren konuşmayan işitme engelli çocuklar, gündüzlü ve yatılı özel eğitim okullarında eğitim almaktadırlar. Genelde geç tanılanan ve konuşma gelişimi olmayan çocukların devam ettiği bu okullarda öğrenci sayılarını yıllara göre azaldığ 1 dikkati çekmektedir. 1996-1997 yılında 6042, 2015-2016 yılında 4.722 ve 2017-2018 y1lında ise 3.753 öğrenci olduğu ve sayının yıllara göre azaldığı dikkat çekmektedir (Kemaloğlu ve Yaprak Kemaloğlu, 2012; Kemaloğlu, 2014a; MEB Resmi İstatistikleri, 2018). 15 Ocak 2019 tarihinde ilan edilmiş Milli Ĕ̈itim Bakanlığı resmi istatistiklerine göre (https://sgb.meb.gov.tr>www>resmi-istatistikler), Türkiye'de 2017-2018 eğitim öğretim döneminde 35 işitme engelliler ilkokulunda 674 öğrenci ve 35 işitme engelliler ortaokulunda 1.193 öğrenci eğitim alırken; 20 işitme engelliler özel eğitim meslek lisesinde toplam 1.886 öğrenci eğitim görmüştür. 2018-2019 yılı verileri incelendiğinde ise 32 işitme engelliler ilkokulunda 674, 32 işitme engelliler ortaokulunda 1068 ve 20 işitme engelliler özel eğitim meslek lisesinde 1690 olmak üzere; toplam 3432 öğrenci ayrı ortamda eğitime devam etmiştir (MEB Resmi İstatistikleri, Ağustos, 2018, Eylül, 2019). Öte yandan erken tanılama, cihazlama ve erken işitsel sözel eğitime bağlı olarak kaynaştırma eğitimine giden işitme engelli çocukların sayısında artış gözlenmektedir (İlkbaşaran, 2016; Kemaloğlu, 2016a). Örneğin, 2018-2019 y1lında kaynaştırma eğitimine okul öncesi düzeyde 1260, ilkokul düzeyinde 115.556, ortaokul düzeyinde 130.624 ve ortaöğretim düzeyindeki okullarda 48.257 öğrenci akranları ile eğitime devam etmiştir. Oysa bu rakam 2017-2018 yılı istatistiklerinde okul öncesi düzeyde 2601, ilkokulda 105.098, ortaokulda 108.753 ve ortaöğretim de 41.318 iken; 2010-2011 y1lında ilköğretim düzeyi için 84.580 ve ortaöğretim düzeyi için 7775 öğrencidir (MEB, Örgün Eğitim İstatistikleri, 2010-2011; 2017-2018, 2018-2019).

Türkiye İstatistik Kurumu Engellilerin Sorun ve Beklentileri Araştırması (TÜIK-ÖSBA)'na göre işitme engellilerin \%47.7'si işitme engelliler okullarında, sadece \%28.6'sı kaynaştırma okullarında eğitim almak istedikleri yönündedir (TÜIK-ÖSBA, 2010:40). Ancak bu okullarda ilkokul yaşına kadar konuşma gelişimini sağlamamış olan çocuklara 2016 yılına kadar sadece işitsel sözel eğitim verilmekteydi (Kemaloğlu, 2016ahttp://orgm.meb.gov.tr/www/turk-isaret-dili-dersiogretim-programi-yururlukte/icerik/766). Son yasal düzenlemelerle birlikte 2015-2016 öğretim yılından itibaren işitme engelliler okullarında çalışan öğretmenlere TíD (Türk İşaret Dili) eğitimi verilmekte, TID'de eğitim materyalleri ile TíD temelli bir okuma yazma çalışmaları yürütülmektedir. 
İşitme engelli çocukların bir kısmı işaret dili ile eğitim alacak grupta yer almaktadır. İşaret dili, işitme engelli bireylerin kullandıkları iletişim yöntemlerinden birisidir (Piştav Akmeşe, 2020:57). İşitme engelli çocuklarla yapılan çalışmalarda dikkati çeken başlıca noktalar erken tanı, erken müdahale, ailenin desteklenmesi, çocuğun okul yaşamında işaret dili ile öğretime yer verilmesi, nitelikli ve erişilebilir özel eğitim desteği, odyolog, ebeveynler, dil konuşma terapistleri, öğretmenlerin işbirliği ile izleme ve değerlendirme çalışmalarıdır (ASHA, 2018a, b; Piştav Akmeşe ve Kayhan, 2016b:88; Sevinç, Aslan ve Özkan, 2013:11). Gerek okul öncesi gerekse diğer kademelerde, işitme engelli çocukların eğitimlerinde işaret dilinin kullanımına yönelik yapılan çalışmalar incelendiğinde Piştav Akmeşe (2015:341-345), işitme engelli çocukların erken yaşlarda işaret dili ile eğitimlerine başlanmasını ve okul çağında TỉD yeterliğine sahip öğretmenlerce desteklenmesinin önemine değinmiştir. Ayrıca Piştav Akmeşe, öğretmenlere TíD eğitimlerinin yetişkin eğitimi ve eğitici eğitimlerini tamamlamış bu konuda formasyonu olan personeller tarafından verilmesi gerekliliğini belirtmiştir. Bowman-Smart, Gyngell, Morgan ve Savulescu (2019:1) ise okullarda işaret dili kullanımına yer verilmesini, çocuklar için etkili bir öğretimi sağlamak ve adaletli davranmak açısından önemli bir nokta diye belirtmişlerdir. Bir diğer araştırma bulgusu ise işitme engeli olan çocukların eğitiminin yalnızca öğretmenlerin iletişim ve işaret dili yeterliklerine bağlı olmayıp aynı zamanda, sağlık personeli, özel eğitim rehabilitasyon merkezlerinde görev yapan personelin de eğitim, sağlık ve rehabilitasyon açısından rol ve sorumluluklarını işaret etmiştir. Piştav Akmeşe ve Kayhan (2016b:88-102) tarafından yapılan araştırmada işitme engelliler öğretmenleri ile işitme, konuşma, özel eğitim ve rehabilitasyon merkezlerinde çalışan odyoloji ve konuşma bozuklukları uzmanlarının görüşlerine başvurulmuştur. Katılımcıların görüşlerinde dikkati çeken bulgu aile eğitimi ve erken dönemde çocukların işaret dili ve sözel dili birlikte kullanmaları gerektiğine ilişkin görüşleridir. Dolayısıyla işitme kaybı, öğrencilerin iletişim süreçlerini doğrudan etkilediğinden, öğretmenlerin işitme engelli bireylerin eğitiminde kullanılan yöntemleri etkili öğretim planlarına yansıtmaları gerekmektedir (Piştav Akmeşe ve Kayhan, 2016a:296-325; 2016b:103-104). İşitme engelli çocukların okul yaşamını etkileyen birçok faktör bulunmaktadır. Ebevyen, öğretmen ve akranları ile ilişkileri, tutumlar, fiziksel düzenlemeler, öğretmenlerin etkili öğretim becerileri, ebeveyn katılımı, öğretimde işaret diline yer verilmesi, bireyselleştirme ve özel eğitim desteği bu faktörlerden bazılarıdır. Nitekim Odluyurt ve Batu (2012:33) işitme yetersizliği olan öğrenciler için öğretmenlerin dikkat etmesi gereken bir takım ilkelerden söz etmişlerdir. Örneğin öğretmenin işitme engelli öğrencisine yüzü dönük bir şekilde ders anlatması, sınıfta iletişim kurmak açısından işiten öğrencilere rol model olması, fiziksel düzenlemeler ve öğretimsel uyarlamalar yapması gibi. Ancak eğitim öğretim uygulamaları, özel gereksinimleri olan çocukları yalnızca kuruma yerleştirme ile biten bir süreç değildir (Sucuoğlu ve Kargın, 2006:29). İşitme engelli çocukların da yalnızca ilkokul eğitimine devam etmiş olmaları, okuma yazma becerileri açısından yeterli olmayabilir (Traxler, 2000). Piştav Akmeşe ve Kayhan, (2018a: 148-149; 2018b:149-154155) işitme engeli olan bireylerin iletişim kurmak amacıyla kullandığı yöntemlerden biri olan işaret dilinin, tam ve kapsayıcı bir dil olduğunu, öğretmenlerin işaret dilini bilmelerinin ve öğretimde kullanıyor olmaları ile işitme engelli çocukla çalışma yeterliklerinin önemine değinmişlerdir. İşaret dili yeterliğinin okuma becerisini yordadığını ifade eden Chamberlain ve Mayberry (2008) ise eğitim ortamlarında derslerin akademik erişilebilirliği ve öğrencilerin katılımı açısından öğretmenlerin işitme engelli çocuklar hakkında bilgi sahibi olmalarının ve işaret dili kullanımının önemine dikkat çekmişlerdir.

Reagan'a (2010) göre işitme engeli olan çocukların eğitiminde iki temel nokta bulunmaktadır. Biri, işitme engelli çocukların işaret dili edinimi, diğer konu ise normal işten bireylerin işaret dilini öğrenmesidir (akt., Kubuş, İlkbaşaran ve Gilchrist 2016). Dolayısıyla ev ortamında ve eğitim öğretim sürecinde işaret diline yer verilmesi kadar toplumsal yaşamda işaret dili kullanımı da önemlidir. Çünkü her birey, tercih ettiği iletişim yöntemini kullanabilme hakkına sahiptir. İşaret dili işitme engelli bir çocuğun doğal olarak öğrenip kullandığı bir dildir. Okulda, ailede, sosyal yaşamda onun birincil dili olarak adlandırılmaktadır (Mann, Haug, Kollien ve Quinto- 
Pozos 2015). İşitme engelli bireylerin daha iyi eğitim alabilmeleri için işitme engellilerle çalışacak öğretmenlerin işaret dilini bilerek mezun olmaları (Piştav Akmeşe ve Kayhan 2016a:296, 2016b:103, 2017:32-33, 2018a:148, 2018b:154-155); işitme engelliler okulları ile kaynaştırma ortamlarında görev alacak öğretmenlerin de işitme engeli hakkında bilgi sahibi olmaları ve işitme engelli bireylerin özelliklerine uygun eğitim sunabilme yeterlikleri ile yetiştirilmesi gerekmektedir. Öğretmenlerin bu becerilere sahip olması, işitme engelli çocukların anadillerini kullanarak, öğretimde firsat eşitliğine dayalı eğitim görmeleri açısından önemli bir noktadır (Bowman-Smart, Gyngell, Morgan ve Savulescul, 2019:94). Dolayısıyla işitme engelli çocuklara sağlanan eğitim firsatlarının, onlarla çalışacak öğretmenlerin lisans dönemi eğitimleri ile ilişkili olduğu söylenebilir. Çünkü öğretmen adayları aldıkları teorik derslerle birlikte çalışacakları öğrenci gruplarında gözlem verisi toplama ve ders planı hazırlayıp, öğretim gerçekleştirdiklerinde mesleki deneyim elde etmektedirler. $\mathrm{Bu}$ deneyim ayırtedici bir kazanım olup öğretmen eğitiminin, meslek öncesi ve meslek içi devam eden bir süreç olduğunu açıklamaktadır. Sonuç olarak, öğretmen yeterlikleri ile nitelikli öğretim arasında bir ilişki bulunmaktadır (Fritsch, Berger, Seifried, vd. 2015:1). Trittel, Low ve Schmitz (2014:6364), mesleğini bir eylem planı çerçevesinde gerçekleştiren öğretmenlerin öncelikle öğrencinin bireysel farklılıklarını temel alarak doğru bir değerlendirme yapabildiklerini, ardından öğrenci ve ebeveynle ortak karar alarak etkili bir plan hazırlayabildiklerini, planlarını uygularken sinıf yönetiminde adil davrandıkları ve davranış gözlemi yaptıklarını, veri kaydedip öğrenciye geri bildirimi etkili biçimde verdiklerini ifade etmişlerdir.

Louws, van Veen, Meirink ve van Driel (2017:487), öğretmenlerin kendileri için tanımladıkları mesleki öğrenme hedefleri ile öğretmenlik deneyimleri arasındaki ilişkiyi inceledikleri çalışmalarında farklı kıdeme sahip 16 öğretmenle görüşmüşlerdir. Deneyime göre mesleğin ilk yılları, orta kıdemde ve ileri düzey kıdemde personel gruplaması yapmışlardır. Farklı mesleki deneyime sahip olsalar da öğretmenlerin kişisel mesleki gelişim hedeflerinin benzerlik gösterdiğini çoğunlukla iletişim, işbirliği becerileri ile müfredat, öğretim yöntem teknikleri, etkili öğretim konularında değişime açık oldukları sonucuna varılmıştır. Kariyerinin ilk yılları ile ortalarında olan öğretmenlerin mesleki gelişim hedeflerinin merkezinde müfredat bilgisi, etkili öğretim konuları öne çıkarken; ileri kıdeme sahip öğretmenlerin daha sıklıkla müfredat dışı etkinlikler ile eğitimde yenilikler hakkında bilgi edinmek istedikleri belirlenmiştir. Bu sonuçları mesleki yaşam evre modeli olarak tanımlayan araştırmacılar, öğretmenlerin konu alan uzmanlığını önemli gördükleri ve öğretimi bireyselleştirme noktasında yeterlik kazanma hedeflerinin olduğu şeklinde ifade etmişlerdir. Fernandez, Gonzalez ve Subirats (1988:123-124) ise öğretmen eğitiminde uygulama derslerinin önemine ve nasıl yürütüldüğüne dair bir araştırma gerçekleştirmişlerdir. Barselona Üniversitesi Öğretmen Kolejinde gerçekleşen araştırmaya stajyer lisans öğrencisi, kıdemli öğretim üyesi ve uygulama öğretmeni katılmıştır. İlkokul düzeyindeki öğretmenlik uygulamalarının incelendiği çalışmada, aday öğretmenlerin fakülte ve uygulama okulundaki öğretmenler ile çalışmaları performans temelli bir süreç olarak tanımlanmıştır. Aday öğretmenlerin gözlem yaptıkları sınıflarda uygulama öğretmenlerinden mesleğin işlevi hakkında deneyim sağladıkları, ayrıca öğretmenlerin ne tür yeterliklere sahip olması gerektiği ile ilgili kazanımlar elde edebildikleri, öğrenciler ve ebeveynlerine karşı olumlu tutum geliştirme firsatları elde ettikleri belirtilmiştir. Dolayısıyla öğretmen adaylarının mesleğe hangi koşullar altında hazırlandıkları, uygulama süreleri ve meslekteki öğretmenler ile fakültedeki uygulama sorumlusu öğretim üyelerinden ne tür geribildirim aldıkları önem arz etmektedir.

2019 Aralık ayında görülmeye başlayan ve tüm dünyayı etkisi altına alarak küresel bir salgın haline gelen Covid-19 hastalığı nedeniyle ülkemizde de, Milli Eğitim Bakanlığına (Özer, 2020:1124) ve Yükseköğretim Kuruluna bağlı eğitim kurumları, uzaktan eğitim uygulamalarına geçmiştir (YÖK, 2020b). Milli Eğitim Bakanlığı'na (2020) ait uzaktan eğitim uygulamaları Dünya Bankası'nca Ülkelerin Covid-19 sürecinde eğitimi desteklemek adına uzaktan eğitime erişimi (çevrimiçi öğrenme, radyo, televizyon, mesaj içerikleri) ne şekilde kullandıklarına ilişkin rapor yayınlanmıştır. 
Raporda Eğitim Bilişim Ağı (EBA) üzerinden yapılan canlı yayınlara ve hazırlanan çevrimiçi içeriklere, Televizyon, Radyo programlarına vurgu yapılmıştır. EBA, Türkiye'de dijital bir eğitim platformu olarak tanımlanırken, MEB'e bağlı eğitim kademelerinde öğrenim gören öğrenciler ile görevli öğretmenlerin, ayrıca velilerin de akıllı telefonlar aracılığıyla erişimlerinin olduğuna dikkat çekilmiştir (Dünya Bankası, 2020). Dünya Sağlık Örgütü tarafından 11 Mart 2020 tarihi itibariyle küresel salgın ilan edilmesiyle Türkiye Yükseköğretim kurumlarında da 16 Mart 2020 tarihinde eğitime 1 hafta ara verilmiş, bu sürede kurumların uzaktan eğitim alt yapı sistemleri incelenerek hazırlıklar yapılmıştır. 23 Mart 2020 itibariyle ders anlatımları, sınavlar dahil olmak üzere eğitimöğretim dijital ortamda uzaktan eğitim şeklinde yürütülmüsstür (Yükseköğretim Kurumu-YÖK, 2020a,b).

Eğitim ortamlarında yerel, ulusal veya küresel beklenmedik durumlara yönelik acil eylem planları hazırlanmakta, bu planlar doğrultusunda stratejik kararlar alınmaktadır. Covid-19 nedeni ile yükseköğretim kurumlarında uygulamalı derslerin ilk 5-6 hafta içerisinde gerçekleştirilmesi temel alınarak, salgının devam ettiği dönemde teorik derslerin uzaktan eğitim ile devam etmesi ve yüzyüze eğitime ara verilmesi kararı da buna örnek oluşturmaktadır. Eğitim Fakültesi özel eğitim programında öğrenim gören öğretmen adayları da bu sürecin katılımcıları arasında yer almıştır. Öğrencilerin teorik derslerle başlayan uzaktan eğitim sürecine uygulamalı dersler de dahil edilmiştir. Dolayısıyla öğrenciler, dönem boyunca programdaki derslere dijital ortamda katılmışlardır.

Lisans programındaki uygulamaya yönelik dersler incelendiğinde 2. Sınıf bahar döneminde Özel Eğitim Kurumlarında Gözlem, 3. Sınıf bahar döneminde Özel Eğitimde Okul ve Kurum Deneyimi ile 4.Sınıfta Güz ve Bahar dönemlerinde Özel Eğitimde Öğretmenlik Uygulaması dersleri olduğu görülmektedir. 2. sınıfta alınan Özel Eğitim Kurumlarında Gözlem dersinde farklı engel guplarında öğrencilerin eğitim aldığı okullarda dönüşümlü olarak gözlem yapan öğretmen adayları; 3. Sinıfta Özel Eğitimde Okul ve Kurum Deneyimi dersi ile 4. sinıfta her iki dönem Özel Eğitimde Öğretmenlik Uygulamasını özel eğitim öğretmenliğinde uzmanlaşacakları alt alanda eğitim alan öğrencilerin devam ettikleri okulara giderek tamamlamaktadırlar. Öğretmen adaylarının 2019-2020 Bahar yarıyılı uygulama derslerini uzaktan eğitim deneyimlerinin incelenmesi, dijital ortam yeterlikleri, uygulama dersi beklentileri, öğretmenlik uygulamalarına bakış açıları ile uzaktan eğitim sürecinde yaşantılarına bağlı görüş ve önerileri anlamında önemli görülmektedir. Öğretmen adaylarının uzaktan eğitim yoluyla deneyimledikleri uygulama derslerine ilişkin görüş ve önerilerinin, dijital çağda öğretmen yetiştirme sistemi ile ilgili alınacak kararlara, öğretmenlerin meslek öncesi yetişmesi anlamındaki planlamalar ile fakülte-uygulama okulu işbirliği süreçlerine katkı sağlayacağ 1 düşünülmektedir. Bu çalışmada, küresel salgın olarak ifade edilen koronavirus (COVID-19) salgın sürecinde yükseköğretime devam eden özel eğitim bölümü üçüncü ve dördüncü sınıf öğrencilerinin uygulama derslerinin uzaktan eğitim ile yürütülmesine yönelik deneyimlerinin incelenmesi amaçlanmıştır. Bu temel amaca bağlı olarak araştırmada yanıt aranan sorular:

Özel eğitim bölümü öğrencilerinin,

1- Uzaktan eğitime ilişkin görüşleri nelerdir?

2- Uzaktan eğitim yöntemi ile işlenen uygulama derslerine yönelik görüşleri nelerdir?

3- Uzaktan eğitim sürecinde yaşadıkları güçlükler nelerdir?

4- Uzaktan eğitim ile verilen uygulama derslerinde öğretimsel düzenlemelerle ilişkili deneyimleri nelerdir?

5- Yükseköğretimde uzaktan eğitimin daha etkili bir biçimde verilmesine ilişkin görüş ve önerileri nelerdir? 


\section{Yöntem}

Betimsel desende gerçekleştirilen bu çalışmada, Covid-19 salgın süresince yükseköğretime devam eden özel eğitim öğretmenliği öğrencilerinin uzaktan eğitim ile yürütülen uygulama derslerine ilişkin deneyimleri incelenmiştir. Çalışma amaçlı örnekleme ölçütüne göre gerçekleştirilmiştir. Özel eğitim öğretmenliği öğrencilerinin Covid-19 salgın döneminde erişilebilirlik anlamında deneyimleri, uygulama derslerinin içerik ve değerlendirme süreçleri, uzaktan eğitim derslerinde yapılan uyarlamalar, meslek öncesi hazırlık süreci ve lisans eğitiminin öğretmen yeterliklerindeki önemine ilişkin görüşleri alınmıştır. Katılımcı öğretmen adaylarının görüşlerini temel alan bu araştırma, nitel yönteme göre gerçekleştirilmiştir (Creswell, 2012:1-12-160).

\section{Örneklem/Katılımcılar}

Araştırmanın verileri, Ege Bölgesinde yer alan devlet üniversitelerinden birinin eğitim fakültesi özel eğitim bölümü öğretmen adaylarından elde edilmiştir. Çalışmada amaçlı örneklem tercih edilmiş ve şu ölçütler aranmıştır. Katılımcı öğretmen adaylarının:

a) Özel eğitim bölümü üçüncü ve dördüncü sınıfa devam ediyor olması,

b) İşitme yetersizliği alt alanında aldığı seçmeli dersler ve işitme engelliler okullarında yaptığı uygulamalar ile işitme alanında uzmanlaşacak olması,

c) 2019-2020 Bahar döneminde kayıt dondurmamış veya farklı bir nedene bağlı eğitime ara vermeden, uzaktan eğitim deneyimini yaşamış olması,

d) Çalışmaya gönüllü katılım göstermeyi kabul etmiş olmasıdır.

Bu ölçütleri karşılayan ve katılımı kabul eden aldıkları seçmeli dersler ile işitme yetersizliği alanında uzmanlaşan Özel Eğitimde Okul ve Kurum Deneyimi dersini uzaktan eğitim ile alan 6 öğrenci ile Özel Ĕgitimde Öğretmenlik Uygulaması dersini alan 3 öğrenci katılmıştır. 9 katılımcı da, 2019-2020 bahar yarıyllında Özel eğitimde okul ve kurum deneyimi ve Özel eğitimde öğretmenlik uygulaması derslerini ilk dört hafta yüz yüze almışlar, sonraki 4 hafta ise uzaktan eğitim yoluyla almışlardır. Katılımcıların cinsiyet, sınıf düzeyleri uzaktan eğitim ile almış oldukları uygulama dersi, evinde bilgisayar ve/veya tablet olma durumu, uzaktan eğitim süresinde evde yaşayan birey sayısı ile uzaktan eğitim alan kişi sayısına ilişkin bilgiler Tablo-1 de belirtilmiştir.

Tablo 1: Katılımcıların Demografik Özellikleri

\begin{tabular}{|c|c|c|c|}
\hline Öğr No Cins & Sınıf Düz. Alınan Uygulama Dersi & Evde Bilg.var mı? & $\begin{array}{cc}\text { Evde kişi Sa. } & \text { Uz.Egt. } \\
\text { Alan Kişi Sa. }\end{array}$ \\
\hline Erkek & Özel Eğitimde Okul ve Kurum Den. & Bilg. var & 1 (Kendisi) \\
\hline Erkek & Özel Eğitimde Okul ve Kurum Den. & Bilg. var & 2 (2 Üni. Öğr \\
\hline Erkek & Özel Eğitimde Okul ve Kurum Den. & Bilg ve dizüst bilg. var & 2 (1'i Lise Öğr) \\
\hline Kadın & Özel Eğitimde Okul ve Kurum Den. & Tablet var & 2 (2 Üni. Öğr) \\
\hline Kadın & Özel Eğitimde Okul ve Kurum Den. & Birden fazla bilg. var & 2 (1’i Lise öğr) \\
\hline Erkek & Özel Eğitimde Okul ve Kurum Den. & Bilg ve dizüst bilg. var & 3 (1 ilkokul 2 Ün) \\
\hline Erkek & Özel Eğitimde Öğretmenlik Uyg. & Diz üstü bilg var & 2 (1'i Lise) \\
\hline Erkek & Özel Eğitimde Öğretmenlik Uyg. & Diz üstü bilg var & 1 (Kendisi) \\
\hline Erkek & Özel Eğitimde Öğretmenlik Uyg. & Diz üstü bilg var & 1 (Kendisi) \\
\hline
\end{tabular}

Tablo1'e göre öğretmen adaylarının çoğunluğu erkek (7 katılımc1), 6'sı 3. Sınıf düzeyinde ve Özel Eğitimde Okul ve Kurum Deneyimi dersini almıştır. Tamamının evinde internet bağlantısı olduğu, bilgisayar veya tabletleri bulunduğu, yalnızca 4 öğrencinin (ÖA3, ÖA5, ÖA6, ÖA9) kişisel bilgisayarın bulunduğu dikkati çekmiştir. Covid-19 salgın sürecinde evde yaşayan kişi sayıları incelendiğinde en kalabalık aile ortamının 7 kişi olduğu (ÖA7), 1 öğrencinin (ÖA9) ise yalnız 
yaşadığı belirlenmiştir. Çoğunlukla 4-5 kişilik aile ortamında yaşayan öğrencilerin kardeşleri ile birlikte uzaktan eğitim aldıkları, bu nedenle evde 2 veya 3 öğrencinin uzaktan eğitime devam ettiği görülmüştür (ÖA2, ÖA3, ÖA4, A5, ÖA6, ÖA7).

\section{Veri toplama yöntemi}

Veri toplama süreci, çalışma nitel araştırmada desenlendiği için görüşme tekniğine göre planlanmıştır. Yazarların her ikisi de özel eğitim alanında doktora derecesine sahiptir ve bulundukları üniversitede Özel eğitimde okul ve kurum deneyimi ve Özel eğitimde öğretmenlik uygulamas1 derslerini yürütmektedirler. Ayrıca Yükseköğretim kurumunda eğitime devam eden öğrencilerin akademik, sosyal, kültürel faaliyetlere tam katılımları noktasında Türk İşaret Dili (TID), işitme engelli bireylerin eğitimi ve öğretimsel uyarlamalar konularında da akademik bilimsel çalışmalar, projeler yürütmektedirler. Çalışmada etik kurul izni alınmıştır (03.11.2020 Sayı:E--804.01BABBFCF3).

Özel eğitimde okul ve kurum deneyimi ve Özel eğitimde öğretmenlik uygulaması dersini alma ölçütleri karşılayan öğrencilerle e-posta ya da telefon ile iletişime geçilmiştir. Her iki yazar tarafından öğrencilere öncelikle çalışmanın amacını anlatan içerik yazısı ile bilgilendirme yapılmıştır. Ayrıca kabul ve bilgilendirme formu, katılımcılara e-posta ile iletilmiştir. Ardından online ya da telefonla görüşme gün ve saat aralığı planlanmıştır. Planlanan günde görüşmeler telefon ya da online olarak gerçekleştirilmiştir. Görüşmeler, ortalama olarak 20-25 dakika sürmüştür.

\section{Veri toplama aracı}

Çalışmanın verileri araştırmacılar tarafından hazırlanan görüşme formu ile toplanmıştır. Formun hazırlık sürecinde alan yazın bilgisi, öğretmenlik programlarında uygulama dersleri ve öğretmen yeterlikleri, işitme engelli bireylerle çalışacak öğretmenlerin yetiştirilmesi, uzaktan eğitim, dijital ortamda öğretim tasarımları, erişilebilirliği temel alan 8 açık uçlu soru oluşturuldu. Özel eğitimde okul ve kurum deneyimi ve Özel eğitimde öğretmenlik uygulaması dersini yürüten 3 öğretim üyesinin görüşüne sunuldu. Uzmanlar soruları birbirine benzerliği, uzaktan eğitimde uygulama derslerinin yürütülmesi amacına uygunluğu ve lisans öğrencileri tarafindan anlaşılırlık derecesine göre değerlendirmişlerdir. Gelen öneriler arasında 2 sorunun birleştirilebileceği yer almış, ona göre sorular yeniden düzenlenmiştir. Formun son halinde 6 açık uçlu soru yer almıştır. Görüşme sorularından birkaçına Tablo 2'de yer verilmiştir.

Tablo 2: Görüşme Sorularına Örnekler

S-1) Covid19 ile uzaktan eğitim sürecine geçişinizden bahseder misiniz? Nasıl bir bilgilendirme yapıld1, bu süreçte neler yaşadınız?

S-2) Ögretmen adaylarının eğitimlerinin (teorik ve uygulama) nasıl planlanması gerektiğini düşünüyorsunuz?

Uzaktan eğitim ve yüz yüze eğitime ilişkin uygulamaların etkililiği hakkında görüşleriniz nelerdir?

S-3) Size göre uzaktan eğitim sürecinizi etkileyen faktörler nelerdir?

Katılımcıların görüşme sorularına verdikleri yanıtlar betimsel indeks formuna aktarıldığında, görüşlerin benzerlik ve farklılık gösteren yanları belirlenmiş, NVivo programı kullanılarak içerik analizi ile derinlemesine incelenmiştir. Birbirine benzeyen yanıtlar aynı şekilde kodlanmış, bütüncül bir biçimde temalar oluşturulmuştur (Yıldırım ve Şimşek, 2008:147-227-228). Çalışmada katılımcılara, kendilerine ait bilgilerin gizliliğinin korunacağı ve etik ilkelere göre analiz edileceği açıklanmıştır. Bu anlamda her öğrenci için Öğretmen Adayı (ÖA) ve Sıra No $(1,2,3$,) ÖA1, ÖA3 kodlamaları yapılmışıtır. Veri dökümlerinde kodlayıcılar arası güvenirlik analizi Güvenirlik=[Görüş birliği /(Görüş birliğgi + Görüş ayrılığı)] x 100 formülüne göre \%93 olarak hesaplanmıştır (Miles ve Huberman, 1994:64).

\section{Bulgular ve Tartışma}


Bu bölümde öğretmen adaylarının uzaktan eğitim sürecindeki deneyimlerine göre şekillenen ana tema ve alt temalara yer verilmiştir. Her bir ana temada yer alan görüşler alan yazında öğretmen yetiştirme, işitme engellilerin eğitimi, işitme engelli öğrencilerle çalışacak personel yeterlikleri, öğretmen eğitiminde uygulamalar ve buna yönelik yasal düzenlemeler ile ilişkili biçimde bulgular çerçevesinde tartış1lmıştır.

Özel eğitim öğretmenliği okuyan öğretmen adaylarının, uzaktan eğitim ve uygulama derslerine ilişkin deneyimleri hakkındaki görüşlerine ait alt ve ana temalar Tablo 3'de verilmiştir.

Tablo 3: Ana ve alt temalar

\begin{tabular}{|c|c|}
\hline & $\begin{array}{c}\text { Toplam frekans } \\
\text { sayısı }\end{array}$ \\
\hline $\begin{array}{l}\text { 1-Sürecin getirdikleri } \\
\text { a) Hazırlık ve geçiş (okul-ev-toplum) (ÖA1, ÖA2, ...̈̈A9) } \\
\text { b) Sistem-kişiler rol ve sorumluluklar (ÖA1, ÖA2, ÖA5, ÖA6, ÖA7, ÖA8, ÖA9) } \\
\text { c) Şeffaf ve bilgilendirme tercihleri (ÖA1, ÖA2, ÖA3, ÖA4, ÖA5, ÖA6, ÖA8) }\end{array}$ & 23 \\
\hline $\begin{array}{l}\text { 2-Süreçte yaşananlar } \\
\text { a) Belirsizliğe bağll yaşantılar (ÖA1, ÖA2, ÖA4, ÖA6, ÖA7,ÖA8; ÖA9) } \\
\text { b) Illetişim (ÖA1, ÖA2, ÖA3, ÖA4, ÖA5, ÖA6, ÖA7, ÖA8, ÖA9) } \\
\text { c)Bireysel farklıllklar-imkanlar (ÖA1, ÖA2, ÖA4, ÖA6, ÖA8) } \\
\text { d)Teknolojiyle ilgili deneyimler (Akademisyen-ögrenci) (ÖA1, ÖA2, ÖA4, ÖA6, ÖA8) }\end{array}$ & 26 \\
\hline $\begin{array}{l}\text { 3-Koronavirüs (Covid-19) sürecinin öğrettikleri } \\
\text { a) Erişilebilirlik (ÖA1, ÖA2, ... ÖA9) } \\
\text { b)Mesleki beklentiler (ÖA1, ÖA2, ÖA3, ÖA4, ÖA6, ÖA7, ÖA8, ÖA9) } \\
\text { c)Güçlükler (Süreç-uygulama değerlendirme) (ÖA1, ÖA2, ÖA3, ÖA4, ÖA6, ÖA7, ÖA8, ÖA9) }\end{array}$ & 25 \\
\hline 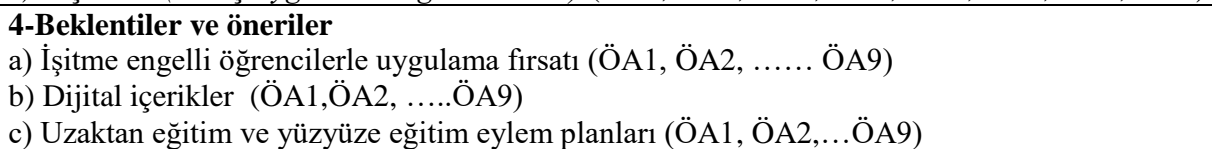 & 27 \\
\hline
\end{tabular}

Tablo3'e göre ana temaya ait toplam frekans sayısı, her bir öğretmen adayının birden fazla alt temada görüş bildirdiğini göstermektedir. Toplam frekans sayısı araştırmanın geneli için 101 olup, Sürecin getirdikleri ana teması Hazırlı ve geçiş (okul-ev-toplum), Sistem kişiler, rol ve sorumluluklar ile Şeffaf ve bilgilendirme tercihleri alt temalarından oluşmaktadır. Süreçte yaşananlar ana teması ise Belirsizliğe bağll yaşantılar, Illetişim, Bireysel farklılıklar ve imkanlar, Teknolojiyle ilgili deneyimler alt temalarında betimlenmiştir. Covid-19 salgın sürecinin öğrettiklerine ilişkin Erişilebilirlik, mesleki beklentiler güçlükler alt temalarında görüş bildiren öğretmen adayları; Beklentiler ve öneriler ana temasinda işitme engelli ögrencilerle uygulama firsatlarının oluşturulması, dijital içeriklerin oluşturulması ve uzaktan eğitim ile ilgili eylem planlarının hazırlanması konularında görüş bildirmişlerdir.

\section{Sürecin getirdikleri}

Araştırmaya katılan öğretmen adaylarının tamamı (9 katılımc1) gerek 6 AKTS'lik Özel Eğitimde Okul ve Kurum Deneyimi gerekse 15 AKTS'lik Özel Eğitimde Öğretmenlik Uygulamaları derslerini uzaktan eğitim ile aldıkları Covid-19 salgın sürecinde en çok hazırlık ve geçiş sürecindeki kaygı ve yaşadıkları diğer olumsuz duyguları ifade etmişlerdir. Bu süreçte en çok uzaktan eğitimin nasıl yürütüleceği kimlerin ne tür sorumlulukları olacağ 1 , stajların nasıl yapılacağı ile bilgilendirme ihtiyaçlarının olduğunu ifade etmişlerdir. Örneğin, $\ddot{\boldsymbol{O} A 1}$ Tedbirleri önce bireyler almalı diye düşündüm. Süreci öngörememe nedeni ile hazırlıksız başlangıçlar oldu. ÖA2 Beklenmedik durumlara hazırlıklı olmamam ve süreci kurumların ön görememesi nedeni ile belirsizliğin yarattı̆̆ stres ve korku yaşadım. ÖA3 Sürecin başındaki belirsizliğin yaşattı̆̆ kaygl vardı ama sürecin zaman içinde belirginleş̧mesi ile rahatlama oldu, şeklinde görüş bildirmişlerdir. Öte yandan ev ortamını eğitim ortamına dönüştürmekte de zorlandıklarını ifade eden katılımcılar (ÖA, 2, ÖA3, ÖA4, ÖA5, ÖA6, ÖA7) evde bulunan fiziki imkanları ve uzaktan eğitim almak durumunda olan kişi sayısının da 
etkili bir faktör olduğunu ifade etmişlerdir. Örneğin, $\ddot{O} A 4$, evimizde 2 kişi ve ikimiz de üniversite ögrencisiyiz. Uzaktan eğitim süresinde evde fiziki olanaklar, internet alt yapısı konularında güçlükler yaşadık. ÖA5 ise evde 2 ögrenci (1 üniversite 1 lise) vardı. Ben kendimi hazırlamıştım ancak yine de adapte olmakta zorlandım. Covid 19' un Çin'deki etkilerinden sosyal medya sayesinde haberdardım. Çin'de de üniversitelerin kapatıldı̆̆ını ve online eğitime geçildiğinin haberini almışıım. Yine de böyle bir salgının ülkemize geldiğinde nasıl bir politika izleyeceğimizi bilmiyordum ve online eğitime geçilmek yerine bir sonraki dönem yoğunlaştırılmış- hızlandırılmış eğitime geçeriz diye düşünüyordum, şeklinde görüş bildirmiştir.

Sistemin nasıl işleyeceği ve rol sorumluluklar konularına da değinen katılımcılar, özellikle üniversitelerde online derslerin yalnızca ders içeriklerinin sisteme yüklenip bırakılarak değil, web tabanlı seminer, oturum, iletişim birimlerine e-posta, telefon ve bireysel farklılıklara dayalı alternatif çözümler getirecek teknik-bilgi işlem çözüm birimleri oluşturulmasını da önermişlerdir. Örneğin, $\ddot{\boldsymbol{O} A 7 . . . . A c ̧ ı k c ̧ a s ı ~ g e c ̧ i s ̧ ~ s u ̈ r e c i m ~ h i c ̧ ~ k o l a y ~ o l m a d ı . ~ V e r i l e c e k ~ o l a n ~ a r a n ı n ~ n e ~ k a d a r ~ u z u n l u k t a ~ o l a c a g ̆ ı ~}$ başta farklı verildiği için okul, iş ve ev durumlarımızı sağllklı bir şekilde planlayamadım. Örnek vermek gerekirse. IIlk açıklanan verilecek aranın üç haftayı kapsayacağı düşüncesi ile aile evine okul ile ilgili herhangi bir kaynak kitap getirme ihtiyacı hissetmedik, ödev sorumluluğum olacağını düşünemedim mesela; diyerek yaşadığı kaygı ve planlama sürecinde deneyimine vurgu yaparken; ÖA8 Sistemin ilk başlarda kullanımına ilişkin güçlükler yaşadım. Herşey belirsiz gibi geldi. Ayrıca akdemik takvimde nasıl bir değişiklik olacağını öngöremedim. O süreçte bilgi edinmek için çok çaba gösterdiğimi düşünüyorum. Sosyal medya, okul hocalarımız.. arkadaşlar.. her türlü bilgi kaynağına başvurdum, diyerek sistemin işleyişi, uzaktan eğitime alışma ve uyum süreci ile rol sorumluluklarını belirginleştirme konusunda bilgi, destek gereksinimleri olduğunu belirtmişlerdir.

\section{Süreçte yaşananlar,}

Öğretmen adayları süreçte yaşadıkları deneyimlerini hazırlık ve geçiş süreci sonrası olarak açıklamışlardır. İlkin şok aşaması yaşadıklarını ancak sağlık alanındaki bilgilendirmeleri titizlikle takip ederek, ulusal yayınları ve veri temelli açıklamaları izleyerek Sağlık Bakanlığının koruyucu, önleyici uyarılarını dikkate aldıklarını açıklamışlardır. Ancak ilerleyen günleri eğitim süreçleri bakımından ön görememeleri nedeniyle kaygılarının arttığını vurgulamışlardır (ÖA1, ÖA2, ÖA4, ÖA6, ÖA7,ÖA8; ÖA9). İletişim sinırlılıkları (ÖA1, ÖA2, ÖA4, ÖA6, ÖA8) ve gerek kendilerinin gerekse akademik idari personelin teknoloji deneyimlerinin, fiziki ortam-maddiyat ile diğer firsatlara bağlı güçlükleri dile getirmişlerdir (ÖA1, ÖA2, ÖA4, ÖA6, ÖA8). Öğretmen adaylarının süreçte bazı deneyimlerinin olumlu (iletişim, teknoloji kullanımı, ev ortamı uygunluğu) bazılarının ise akademik ve idari personel arasındaki uyum, bilgilendirme sistematiği, öğrenciden kaynaklanan fiziki koşullara ve teknolojik imkânlara bağlı farklılaştı̆̆ını belirtmişlerdir. Örneğin, ÖA1, .....Derslerimizi site üzerinden işlemeye başladık. Bütün derslerden ödevler aldık ve bu ödevleri tamamlamaya çalıştı. Biz bunlarl yaparken üniversitelerin yazın da eğitim vereceğini öğrendik. Finallerin önce eylül şimdi de haziran ayında olacă̆ını öğrendik. Bu ani değişiklikler bizi olumsuz yönde etkiledi. diyerek uzaktan eğitimle ilgili ön hazırlıkların olması ve bu tür durumlarda öğrencilere bir takım desteklerin (yönlendirme-psikolojik destek, bilgi işlem gibi) verilmesi gerekliliğine dikkat çekmiştir. ÖA2 ve ÖA4, ise ilk bilgilendirme ile verilen aranın geçici olduğu söylenildiği için üniversiteden ve yurttan ayrılırken yanlarına eşya, kitap almadan memleketlerine döndüklerini ifade etmişler. Birçok öğrencinin de benzer durumu yaşadıklarını belirtmişlerdir. Bu konuda, ÖA4.... yanıma kitaplarımın hepsini almadım sadece iki hafta çalışacak kadar not almıştım. Daha sonra bu süre uzatıldı ve ulaşım yasağı gelince kitaplarımı almaya gidemedim. Kargo ile yollayabilecek kimse de yoktu ve bu yüzden sonraki süreçte ihtiyaç duyacağım ders kaynaklarımdan mahrum kalmış oldum, görüşünü bildirmiştir. $\ddot{O} A 2, \ddot{O} A 3, \ddot{O} A 7$ ise sürecin her aşamasında bilgilendirme yapılmasını olumlu bulduklarını belirtmişlerdir. Uygulama derslerine ilişkin YÖK, MEB ve üniversite bilgilendirme kaynaklarını temel aldıklarını ifade eden öğrenciler, uzaktan eğitim sistemlerinde akademik personelin yanı sıra MEB'e bağlı okullarda uygulama koordinatörü 
öğretmenlerinin de katılımının temel alınarak yazılımlar geliştirilmesi gerektiğine, bu yazılımların sesli, çevrimiçi görüşmelere izin verir halde tasarlanması ve ekonomik aynı zamanda mobil erişilebilir olmasını önermişlerdir (Tüm katılımcılar)

ÖA1 Uzaktan eğitim sürecimizde uygulama derslerimiz için fakülte, bölüm, hocamız ile gerekli gördüğümüz durumlarda, ödevler ile ilgili bilgi almak istediğimiz zamanlarda veya ödevleri göndermek istediğimiz zamanlarda iletişim kurduk. Hocamız ile e posta ve üniversite uzaktan eğitim ders sistemi üzerinden iletişime geçtim. Ama uygulama okulu ögretmenlerimiz ile maalesef uzaktan eğitime geçtiğimiz günden sonra hiç konuşamadık. Uzaktan ĕgitim bazı ayrıcalıkları ortadan kaldırabilir, erișilebilir duruma getirebilir ama uygulama dersleri için de bir planlama yapılması gerekir. ÖA6, Teorik derslerde sıkıntı yaşamadım hocalarımızın göndermiş olduğu slaytlardan faydalandım, fakat uygulamalı derslerde zorluk yaşadım. Sistemin altyapısı kendini yenilediği için teorik olarak kolayca bilgiye ulaşabildim. ÖA2 Uygulama dersinde sürece uygun uyarlanmış ödev tercihleri verildi. Bence sistemin en olumlu yanı ögretimsel uyarlamaların dikkate alınmastydl. Uygulama ödevlerimizin uzmanlaşacağımız alana ve uygulama okulumuza özgü uyarlanabilir hale getirilmesini olumlu karşıladım., ÖA3 Uygulama dersleri için yüz yüze eğitimin avantajları (sorulara hemen cevap alma bilgilendirmelerin daha hızlı olmasl).Yüz yüze eğitimde uygulama yapabilme avantajll. Uzaktan eğitim mi, yüz yüze eğitim mi? Bence burada dersin içeriği önemli, çünkü her iki yönteminde avantajlı olduğu noktalar var., ÖA8 Iki dersim ....ders sisteminde gözükmüyordu. Bunun için dersin hocasına mesaj atmıştım. Daha sonrasında bölüm başkanlı̆̆g, merkez ögrenci işleri ile iletişime geçildi vs, sorun basitmiş esasında, çözüldü. İşte yine bunun da sistem hakkında hocaların yeterince bilgilendirilmemesinden kaynaklandiğını düşünüyorum, şeklinde görüş bildirmiştir.

\section{Koronavirüs (COVID-19) salgın sürecinin öğrettikleri,}

Koronavirüs sürecinin gerek ev ortamında gerekse sosyal yaşamlarındaki sınırlılıklara bağlı olarak erişilebilirlik, mesleki beklentiler, güçlükler (süreç-uygulama ve değerlendirme) açısından farklı bir öğrenme süreci olduğuna dikkat çeken öğretmen adayları; özellikle erişilebilirlik kavramının herkes için önemini ifade etmişlerdir. Öğretmen adayları alt yapısıda erişim güçlüğü, telefon internet paketlerinin sınırlı olması, evde fiziksel ortamın uygun olmayıp, kalabalık yaşantı, bilgisayarın kişisel kullanıma ait olup olmama durumu ve teknoloji deneyimlerindeki farklılıklar nedeniyle erişilebilirlikle ilgili güçlükler yaşadıklarını ifade etmişlerdir. Yanı sıra uzaktan eğitimle ilgili bilgi almak amaçlı personele erişimin istenilen düzeyde olmayışı, kullanım kılavuzlarının görsellerle desteklenmiş, anlatımların sesli ve alt yazılı olması gibi faktörleri içermemesi bir bakıma erişilebilirlik anlamında anlamayı zorlaştıran özellikler şeklinde ifade edilmiştir.

Öğrencilerin uzaktan eğitim ile ilgili olumlu görüş bildirdikleri durumlar da bulunmaktadır. $\mathrm{Bu}$ konuda dersin hocası ve iletişimde olunan birimlerin işbirliği, uyumlu çalışmalarının verimi artıracağını düşünmektedirler. Uzaktan eğitimi oldukça verimli bulduğunu belirten işitmede uzmanlaşacak öğrencilerin mutlaka yüzyüze eğitimin yanı sıra alt yazı sistemlerinin kullanımının olduğu, dijital içerikte animasyon hazırlama, çevrimiçi görüşmelerde işitme engellli öğrencilere ders anlatımı gibi konularda becerilerinin desteklenmesi gerektiğini vurgulamışlardır (ÖA2, ÖA3, ÖA4, ÖA6, ÖA7, ÖA8, ÖA9). Örneğin, ÖA6 Kimlik .....edu adresinden gerekli bilgilendirme yapıldl. Akıllı telefon işimi kolaylaştırdı. Yüz yüze eğitimden sonra biraz zorluk çektim çünkü hiç böyle bir durum başıma gelmemişti. Bu anlamda uzmanlaşılacak alt alanda teknoloji deneyimi önemli. Çünkü özel ĕgitimde nitelikli mezun dediğimizde analiz yeteneği gelişmiş, uyarlama yapabilme becerisine sahip, aile ile iletişim kurabilen, işitme engelli çocuğun ailesini tıbbi alanda da ilgili uzmanlara yönlendirebilen bir öğretmen diyebiliriz. ÖA5 ise özel eğitim öğretmen adaylarının teorik ve uygulama yeterliğine dikkat çekmiştir. Uzaktan eğitim sürecinde yüzyüze eğitimde sağlanılan deneyimleri elde edemediklerini ifade etmiştir. Bu konuda ÖA5 Özel Ĕ̈itim alanı çok kapsamlı bilgileri içermektedir. Tiptan, să̆lı̆̆a, fizyoterapiden psikolojiye birden çok alanı ilgilendiriyor. 
Özel eğitim okuyan bir öğrencinin bu bilgileri teorik yoldan elde etmesi kolay belki ama pratik de yapmalı, öğrencilerle de çalışmal. Derslerin içerisinde uygulama saatlerine yer verilmeli. Örneğin 6 hafta teorik ders verilecekse 6 hafta da uygulama dersleri olmalı. Ögretmen adayları OSB ve Zihin yetersizliği dersini gördükten sonra OSB'li çocukları gözlemlemek için okullarında onları görmeli. DEHB dersinden sonra Öğrenme Güçlüğ̈̈ dersinden sonra bu özel çocuklarla çalışma firsatı bulmall, şeklinde görüş bildirmiştir.

Mesleki beklentiler bakımından da yüzyüze eğitim ile uzaktan eğitimde, deneyim paylaşımına firsat veren dijital ortamlar oluşturulmasına vurgu yapan öğretmen adayları; işitme alanında kullanılan testleri tanımaları için sene içerisinde ziyarete dayalı gözlem yapmalarını önermişlerdir (ÖA5). İşitme engelliler okulunda gözlem, kurum deneyimi uygulamaları sırasında öğretmenlerin işaret dilini kendi imkanlarıyla öğrendiklerini ifade eden katılımcılar, üniversitede İşaret Dilini uygulamalı oarak öğrendiklerini bunun çok önemli bir yeterlik olduğunu belirtmiş̧lerdir. İşitme engelli çocuklarla çalışacak öğretmenlerin işaret dilini bilmesinin önemine değinen öğretmen adaylarından özellikle son sınıf öğrencileri (ÖA7, ÖA8, ÖA9) işaret dili biliyor olmayı meslek öncesi süreçte kazanım ve diğer meslektaşlarına göre avanataj olarak değerlendirmişlerdir.

Uzaktan eğitim sürecinde yaşadıkları güçlüklerin aşılmasında en etkili durumu, ders hocası ve akranlarından aldıkları destekler olarak belirten öğrenciler; Covid-19 salgın sürecinde aynı alt alanda uzmanlaşmayı seçen akadaşları ile uygulama derslerine ilişkin daha sık paylaşımlar yaptıklarını da belirtmişlerdir (Tüm katılımcılar). Örneğin, ÖA4 Bu süreçte daha sik uygulama hocamıza sistem üzerinden ilettim sorularımı. Birkaç gün sonra kendisinden uygulama derslerinin ödevlendirme ile yapılacağına, ödevi sisteme yüklediği ve ödevleri bizden mail yoluyla göndermemizi istediğine dair bir mesaj aldım. Kurum deneyiminde ortak grupta olduğumuz arkadaşlarımızla ödevlerin içeriği hakkında bilgi alışverişi yaptık., diyerek bilgi edinme sürecinde arkadaşlarıyla daha destekleyici ve olumlu paylaşımlar yaptıklarını ifade etmişlerdir. Uzaktan eğitimi ölçme değerlendirme bakımından değerlendiren öğretmen adayları derslere ilişkin değerlendirmelerin gidebildikleri uygulama süresi ile sınırlı olmasını dezavantaj şeklinde tanımlamışlardır. Örneğin, ÖA6 Uygulamalı derslere gidebildiğimiz ilk haftalar edinmiş olduğumuz deneyimlerle, hocamızın vermiş olduğu ödevi hazırladık., ÖA7 Ben, birkaç teorik ders harici uzaktan eğitime karşlyım. Çünkü uzaktan eğitim sürecinde verilen ödevlerin kalıcı öğrenme oluşturmada sinırlıllğg var. Bir ögretmen adayının daha fazlasın yapmaya ve bundan fazlasını öğrenmeye ihtiyacı var. Bu yüzden uzaktan eğitim ve yüz yüze eğitim uygulamalarının etkili olması için kurum gözlemi, sahadaki ögretmen ile birlikte çalı̧̧ma, fakültede ders hocası ile planlama gibi deneyimler de gerçekleştirilmeli, şeklinde görüş bildirmiştir.

\section{Beklentiler ve öneriler}

Öğretmen adaylarının yeterlikler bakımından gerek yüz yüze gerekse uzaktan eğitim sürecine yönelik beklentileri ve önerileri incelendiğinde, işitme engeli olan öğrencilerle ilerleyen süreçte ek uygulama firsatlarının verilmesi, MEB ve YÖK ortaklığında dijital içeriklerin artırılması ve üniversitede bilgi iletişim teknolojilerine dayalı laboratuvar ortamlarının zenginleştirilmesi ile uzaktan eğitim eylem planlarının geliştirilmesi önerilerinin öne çıktığı belirlenmiştir. Uzaktan eğitim eylem planlarının hazırlıklı olma, rol ve sorumlulukların dağılımı ile iş yüklerinin netliği açısından verimliliği artıracağını ifade eden öğrenciler, ani yaşanan değişimlere ayak uydurmak zorunda kaldıklarında belirsizliklerle başetmekte güçlük yaşadıklarını belirtmişlerdir. Örneğin, ÖA1 Süreçte alınacak kararlar önceden belirginleştirilmeli. Yaşanan psikolojik güçlükler bizim açımızdan, eğitim ögretime odaklanmayı zorlaştırabiliyor, şeklinde görüş bildirmiştir. Benzer şekilde ÖA1, ÖA2, ÖA3, ÖA4, ÖA6, ÖA7'de uygulamaya ilşkin kararlarda yapılan değişikliklerin öğrencilerde olumsuz etki bırakabildiğini ifade etmişler; gerek ölçme değerlendirme gerekse akademik takvim ile işleyişteki değişimlere hazırlıksız olmamak adına uzaktan eğitim merkezlerinin kurulmasını, MEB 
ile işbirliği yapılarak uygulama derslerinin uzaktan eğitime entegre edilmesini ve sürece uygulama okulundaki öğretmenlerinin de dahil edilmesi gerektiğini belirtmişlerdir

Beklentiler ve öneriler bağlamında ortaya çıkan bir diğer sonuç ise uzaktan eğitimde beklentilerin daha bütüncül açıdan düşünüldüğü görüşüdür. Öğretmen adayları sisteme ders notlarının yüklenmesi, ödevlerin uyarlanması (Covid-19 salgın sürecinde salgın tehlikesine göre evde yapılabilecek şekilde ders izlencelerinde güncelleme yapılması vb.) öğretim üyelerinin erişilebilir olması, derslerin tekrara izin verecek şekilde kayıtlı olmasının teorik derslere yönelik beklentilerini karşıladığını vurgularken; uygulamalı dersler için uzaktan eğitimde yeni düzenlemeler yapılmasını önermişlerdir. Bu öneriler arasında öğrencilere bilgisayar, internet gibi donanımlarını sağlanması. Görme, işitme ve fiziksel yetersizliği olan öğrenciler için erişilebilir uyarlanmış dizüstü bilgisayar temin edilmesi, internet erişimine öğrencilerin gerektiğinde ödevlerini yapabilmeleri için ikamet yerlerinde belediyeler tarafından şifreli modem kullanımı hakkı tanınması, operatörler tarafından yükseköğretim dahil zorunlu eğitim çağındaki öğrencilerin yaşadığı hanelere internet erişim kotalarının maddi durum, gelir düzeyi, öğrenci sayısı temel alınarak destekleyici yönde artırılması yer almaktadır. Nitelikli mezunların teorik ve uygulamalı derslerde, bilgi ve beceri bakımından iyi yetişmesine de vurgu yapan öğretmen adayları, özel eğitim öğrencilerinin işaret dili ile işitsel sözel eğitim yöntemlerini aktif kullanmaları gerektiğini belirtmişlerdir. Bu konuda $\ddot{O} \boldsymbol{A 3}$, Programda yer alan işaret dili dersinde sınıf mevcudunun 10-15 kişi olması gerektiğini ifade etmiş; ayrıca işaret dilini daha iyi öğrenmeleri için lisans döneminde kullanma firsatları sunulması ile ilgili görüş bildirmiştir. KBB kliniği ve odyoloji bölümüyle işbirliği yapılarak, sağır kültüründen bireyin tanı, değerlendirme, sosyal yaşamı hakkında uzaktan eğitimler yoluyla web tabanlı içerikler hazırlanmasını öneren öğretmen adayları; özel eğitim öğretmenliği öğrencilerinin uygulama yaptıkları okullarla işbirliğinin yalnızca yüzyüze eğitimi değil dijital platformları da kapsayacak şekilde olması gerektiğini ifade etmişlerdir (Öğretmen adaylarının tümü)

İşitme alanında uzmanlaşan öğretmen adaylarının uzaktan eğitim deneyimlerine ilişkin görüşleri incelendiğinde erişilebilirlik, hazırlıklı olma, öğretimsel uyarlamalar, planlama, işaret dili ile öğretim becerisi, meslek öncesi ve meslek içi öğretmen eğitimi ile dijital yetkinlik konularının öne çıktığı belirlenmiştir. İşitme engelli öğrencilerin eğitimlerine yönelik alan yazın incelendiğinde erken tanı, erken müdahale, aile ve okul toplumunda işaret dili kullanımı ve bu öğrenciler için etkili öğretim sunabilecek personel yetiştirmenin zorunluluğu açıkça görülmektedir. Öğretmen adaylarının işaret dilini yeterli kullanabilme becerisine sahip olmak ve uygulama deneyimlerinin bizzat işitme engelli öğrencilerle yapmak açısından görüşleri, alan yazındaki bazı araştırmaların bulgularıyla örtüşmektedir. Örneğin Piştav Akmeşe ve Kayhan (2016a:301), özellikle okul öncesi ve ilkokul döneminde çocukların iletişim ve dil becerilerinin işaretler ve diğer görsellere daha açık olduğunu, özel gereksinimli çocukların eğitimlerinde öğretmenlerin işitsel sözel yöntem ve işaret dilini birlikte kullandıklarında, öğrencilerin derse katılımlarının arttığını belirtmişlerdir. Gürboğa ve Kargın, (2003) doğuştan ileri ve çok ileri derecede işitme kaybı olan işitme engelli bireylerin \%70-75'inin günlük yaşamlarında işaret dilini tercih ettiklerini, Piştav Akmeşe ve Kayhan (2017:30-31) ise öğretmen adaylarının lisans eğitimleri sırasında, işaret dili, dil gelişimi ve iletişim becerileri derslerini yeterli düzeyde almalarının işitme engelli çocukların eğitiminde görev aldıklarındaki uygulamaları açısından önemine değinmiştir. Bu anlamda işaret dili konusuna hakim ve etkili öğretimi sunabilecek öğretmen adaylarının yetişmesinde, lisans dönemi uygulamaları önem arz etmektedir.

Katılımcıların öğretmen eğitiminde yüz yüze ve uzaktan eğitimin birlikte planlanması önerileri de, alan yazında Assunção Flores (2017:127-130) çalışma bulgularıla benzerlik göstermektedir. Assunção Flores, öğretmenlerin kariyerlerinin ilk yıllarındaki en temel endişelerinden birinin etkili bir öğretim için ders planı hazırlamak olduğunu bu anlamda lisans eğitimleri sırasında iyi bir eğitim almaya dönük beklentilerinin olduğunu belirtmiştir. Öğretmen adaylarının da benzer kaygılarına vurgu yapılan araştırmada; özellikle meslek öncesi süreçte 
öğretmenlik programlarına devam eden öğrencilerin hazırladıkları konuya özgü ders planlarına geribildirim verilerek, öğretimde bireyselleştirmeye dayalı uygulama becerilerinin desteklenmesini önermiş̧ir.

Uzaktan eğitim deneyimlerine göre öğretmen adaylarının görüşlerinde dikkati çeken bir diğer bulgu ise öğretmen yetiştirmede dijital dönüşümlerdir. Gerek erişilebilirlik gerekse teknoloji deneyimleri bakımından uzaktan eğitim sisteminin yükseköğretimde firsat eşitliğine dayalı planlanmasını öneren aday öğretmenlerin görüşlerini destekleyen araştırma bulguları mevcuttur. Bu çalışmaya katılan öğrencilerin öğretmen yetiştirme sisteminde teknoloji deneyimleri ile ilgili görüşleri ile akademik personelin kullanıcı yeterliklerinin geliștirilmesi, öğrencilerin bu konuda alt yap1 ve cihaz erişilebilirliklerinin desteklenmesi, yazılımların bireysel farklılıklara dayalı tasarlanması önerileri; Townsend'ın (2011:483-484-497) makalesindeki öneriler ile örtüşmektedir. Dünya'da öğretmen eğitiminin son zamanlarda hızlı teknolojik değişimlerden etkilendiğini belirten Townsend, birçok ülkede öğretmen sayısının artışından çok mesleki yeterliklere sahip öğretmen yetiştirme kavramının temel alındığını ifade etmiştir.

Araştırmada kurum deneyimi ve öğretmenlik uygulaması dersini alan öğrencilerin işitme engelli çocukların özelliklerini öğrenme, tanı, değerlendirme, eğitimlerinde işbirliğinin önemli olduğu ve bu konuda işitme engelliler okulundaki öğretmenlerle birebir uygulama yapmanın gerekliliğine ilişkin görüşleridir. Bu görüş, İngiltere'de öğretmen eğitimi ile ilgili gerçekleștirilen bir araştırmanın bulgusu ile benzerlik gösterdiği söylenebilir. Hopper (2001:211-212) ilkokul öğretmen adaylarının yetișme süreçlerinde meslekteki öğretmenlerle fakülte uygulama koordinatörlerinin işbirliğini incelemiş ve yükseköğretim personelinin mentorluk rolünü yerine getirdiğinde hem öğretmen adayının hem de okuldaki öğretmeninin mesleki olarak gelişim gösterdiğini belirtmiştir. Okul temelli mentorlük kavramı ile açıklanan çalışma bulgularında, öğretmenlik uygulamalarını yürüten akademik personelin stajyer öğrencisi ile işbaşındaki öğretmene, iş başındaki öğretmenin de stajyer öğrenciye geribildirimlerini etkili bir biçimde verdiğinde, sınıftaki etkili öğretim sürecine yönelik bir sistematiğin oluştuğu gözlenmiştir. Buna göre işitme engelliler okulundaki uygulamaları yürütecek akademik personellerin işitme tanı değerlendirme ve rehabilitasyonları açısından deneyim sahibi olması, öğretmen eğitiminde işaret dili yeterliklerine hakim olması önerilebilir. Çünkü işitme engelli bir öğrencinin ders planlaması ve eğitiminde etkili öğretimi sunmak açısından öğretmenlerin öğretim yöntem tekniklerin kullanımı ile ilgili bilgiye ihtiyaçları olabilir. Nitekim alan yazında Piştav Akmeşe ve Kayhan'ın (2016a:88, 2016b;296, 2018b:154-155) çalışmalarında erken tanı, tedavi, işbirliği, işaret dilinin eğitim ve sağlık süreçlerinde kullanımı hakkında gerek öğretmenlerin gerekse odyoloji konuşma bozuklukları uzmanlarının işaret dilini biliyor ve kullanıyor olmaları gerektiği görüşü önemli bir bulgu olarak karşımıza çıkmaktadır. Piştav Akmeşe ve Kayhan (2018b:148-149) tarafından işitme engelli bireylerin eğitiminde öğretimsel düzenlemeler ve Türk işaret dili kullanımı hakkında öğretmen görüşleri başl1klı bir diğer çalışmada, işitme engelli bireylerin devam ettiği bir okulda görev yapan branş öğretmenlerinin, işitme engelli öğrencileriyle iletişim kurma biçimleri, işaret dili kullanımları ile öğretimsel düzenlemeleri gerçekleştirme becerilerine yönelik görüşleri incelenmiştir. Çalışmanın sonucunda, öğretmenlerin çoğunlukla erken müdahale ve erken eğitime vurgu yaptıkları, özellikle Türkçe, Matematik, Fen Bilgisi derslerinde işitme engelli öğrencilerin okuma ve okuduğunu anlama becerilerinin gelişimini nasıl destekleyecekleri konusunda yöntem, teknik ve etkili uygulama örneklerine ihtiyaç duydukları belirlenmiştir.

\section{Sonuç ve Öneriler}

Eğitim öğretimle ilişkili temel kavramlardan biri de okul'dur. Günümüzde bilim ve teknolojik gelişmeler, dijital erişilebilirlik ve bireysel farklılıkların kabul görmesindeki artış, öğrenmenin okul dışında da desteklenmesi ve herkes için nitelikli eğitim yaklaşımlarını da beraberinde getirmiştir. Nitekim, son altı ay içerisinde tüm dünya ülkelerini etkisi altına alan ve küresel bir salgın olan Covid-19 salgın süreci de eğitim-öğretimin devamlılığı, öğrenmenin 
desteklenmesi anlamında yapılan düzenlemeleri etkilemiştir. Uzaktan eğitim uygulaması erken çocukluk ve yükseköğretim dönemi dahil her kademede öğrenime devam eden bireylerin sağlığını tehdit edecek unsurlarla karşılaşmaması açısından önemli bir uygulamadır. Nitel araştırma şeklinde desenlenen bu araştırmada özel eğitim öğretmenliği bölümünde okuyan ve işitme yetersizliği olan çocuklarla çalışabilmek amaçlı işitme alt alanında uzmanlaşan lisans öğrencilerinin uzaktan eğitim ile yürütülen uygulama derslerine ilişkin deneyimlerinin incelenmesi amaçland1. 9 öğrencinin (6's1 özel eğitim VI. Dönem, 3’ü VIII. Dönem) görüşlerine başvurulan çalışmada veri toplama aracı olarak araştırmacılar tarafından geliştirilen görüşme formu kullanıldı. 2020 y1lı Mayıs ayı içinde öğrencilerin sağlığını tehlikeye atmayacak şekilde telefon görüşmeleri ve online görüşmeler ile elde edilen veriler, betimsel olarak analiz edildi. Sonuç olarak öğrencilerin uzaktan eğitim sürecinde uygulama dersleri hakkında görüşler Sürecin getirdikleri, Süreçte yaşananlar, Covid-19 salgın sürecinin ögrettikleri, Beklentiler ve öneriler olmak üzere toplam dört ana temada özetlendi. Öğrencilerin özellikle erişilebilirlik açısından bireysel farklılıklara dayalı düzenleme önerileri ile Covid-19 salgın sürecinin yüzyüze eğitimle birlikte değerlendirilmesi önerisi dikkati çekmiştir. Öğretmen eğitiminde dijital ortamda öğretim tasarımları ile etkileşime fırsat veren düzenlemelerin gerekli olduğunu belirten aday öğretmenler, uygulama derslerinin nasıl planlanması gerektiği ve bundan sonraki süreçlerde uzaktan eğitime yönelik uygulamalarla ilgili de önemli noktalara değinmişlerdir.

Yanı sıra Yükseköğretim kurumlarında dijital ortamlara hazırlık anlamında eylem planlarının gerekliliğine vurgu yaptıkları, bu planlamaların yalnızca üniversite personeli ve öğrencileri değil; aynı zamanda MEB'e bağlı kurumlarda çalışan öğretmenleri ve özel gereksinimleri olan çocuklar ile ailelerini de çevrimiçi ortamda buluşturacak şekilde tasarlanması gerektiğini düşündükleri belirlendi. Bu anlamda tüm dünyayı etkisi alan, viral bir salgın olan Covid-19 salgın sürecinde özel gereksinimleri olan çocukların sağlık, eğitim ve yaşamın diğer alanlarını ilgilendiren düzenlemelerin benzer ve farklılaşan yönleri olduğu söylenebilir. Bu anlamda evde öğrenmeyi destekleyecek planlamaların yapılması, özellikle aileler, öğretmenler ve öğrenciler için erişilebilir, güvenli internet tabanlı öğrenme ortamlarının oluşturulması önem kazanmıştır (Dreeseni vd.2020).

Dünya Sağlık Örgütü (Mart-2020) verilerine göre yeryüzünde 466 milyon işitme engelli birey yaşamakta iken, bunların 34 milyonunu ise çocukların oluşturduğu ifade edilmektedir (Dünya Sağlık Örgütü, 2020). Özellikle sosyal ve duygusal etkiler bakımından içinde yaşadığ katılımını sınırlandıran bir engel olan işitme duyusunun tam kullanılamaması durumu, soyut kavramların anlaşılması, iletişim ve etkileşimlerin sınırlanmasına da yol açabilmektedir (Dünya Sağlık Örgütü, 2020; Piştav Akmeşe, 2020). Bu nedenle özel eğitim öğretmenliğinin alt alanı olan işitme yetersizliği alanında uzmanlaşmak için seçimlik dersler alan ve uygulamalarını işitme engelliler ilk ve ortaokulunda yapan öğrencilerin uzaktan eğitim deneyimlerinin, işitme engellilerle çalışacak öğretmenlerin yetişme süreçlerine katkı sağlayacağ düşünülmektedir.

Sonuç olarak öğretmen eğitiminde yeterliklere dayalı bir sürecin planlanmasında dijital dönüşümler gözardı edilemez. Aynı zamanda yüzyüze eğitim ile uzaktan eğitimin avantajlı yanlarının birlikte uygulanması, gerek akademisyenlerin gerekse öğrencilerin gözüyle değerlendirilebilir. Öğretmen eğitiminde yapılacak nitelikli her düzenlenme, çocuklar için erişilebilir ve nitelikli bir eğitimin sağlanması açısından önem taşımaktadır. Bu araştırma Covid-19 küresel salgın dönemine özgü olması ve işitme alanında uzmanlaşacak öğretmen adaylarını kapsaması yönüyle sınırlılıklar içermektedir. İlerleyen süreçte, özel eğitimin diğer alt alanlarında uzmanlaşan öğrencilerin deneyimlerine yönelik çalışmalar yapılabilir. Ayrıca Covid-19 salgın sürecinde eğitimlerini senkron ya da asenkron yürüten farklı üniversitelerde öğrenim gören özel eğitim öğretmenliği öğrencilerinin, uzaktan eğitim deneyimleri incelenebilir. 


\section{Kaynakça}

American Speech, Language, Hearing Association (ASHA) (2018a). Cochlear implants. http://www.asha.org/public/hearing/Cochlear-Implant/.

American Speech, Language, Hearing Association (ASHA) (2018b). What is hearing loss? https://www.asha.org/public/hearing/Hearing-Loss/.

Assunção Flores, M. (2020). Learning to teach: knowledge, competences and support in initial teacher education and in the early years of teaching, European Journal of Teacher Education, 43(2), 127-130, https://doi.org/10.1080/02619768.2020.1733828.

Batu, E.S. (2014). Kaynaştırmada yasal düzenlemeler. Özel gereksinimli çocukların kaynaştırılması (E.S. Batu, A. Çolak,\& S. Odluyurt, Eds.). Vize Yayıncılık.

Belgin, Erol (2011). Çocuklarda işitme kaybı. Özel eğitim (N. Baykoç, Ed). Eğiten Kitap.

Bolat, H., \& Genç, G. A. (2012). Türkiye ulusal yenidoğan işitme taraması programı: Tarihçesi ve prensipleri. Türkiye Klinikleri J E.N.T.-Special Topics,5(2), 11-4.

Bowman-Smart,H., Gyngell, C., Morgan, A. \& Savulescu, J. (2019). The moral case for sign language education. Monash Bioethics Review, 37, 94-110. https://doi.org/10.1007/s40592019-00101-0.

Creswell, J. (2012). Educational research, planning, conducting and evaluating quantitative and qualtitative research. (Fourth Edition). Pearson Merrill Prentice Hall.

Dikyuva, H., Makaroglu, B., \& Arık, E. (2015). Turkish Sign Language linguistics book. Ministry of Family and Social Policies, Disabled and Elderly Services General Directorate. Impetus Media Production Ltd. Sti.

Dreeseni, D., Akseeri,S., Brossardi, M., Dewanii, P., Giraldoii, J.P., Kameii, A., Mizunoyaiii, S., \& Ortiz, J.S. (2020). UNICEF Promising practices for equitable remote learning Emerging lessons from COVID-19 education responses in 127 countries. https://www.unicefirc.org/publications/pdf/IRB\%202020-10.pdf.

Dünya Bankası (2020). How countries are using edtech (including online learning, radio, television, texting) to support access to remote learning during the COVID-19 pandemic https://www.worldbank.org/en/topic/edutech/brief/how-countries-are-using-edtech-tosupport-remote-learning-during-the-covid-19-pandemic.

Fernandez, M., Gonzalez, R., \& Subirats, A. (1988). The tutor's role in teaching practice in initial teacher training, European Journal of Teacher Education, 11(2), 123-130. https://doi.org/10.1080/0261976880110206.

Fritsch, S., Berger, S., Seifried, J., Bouley, F.,Wuttke, E., Kathleen Schnick-Vollmer, K., \& Schmitz, B.(2015). The impact of university teacher training on prospective teachers' CK and PCK a comparison between Austria and Germany. Empirical Res Voc Ed Train, 7(4). https://doi.org/10.1186/s40461-015-0014-8.

Girgin C, Kemaloğlu Y. (2017). İşitme yetersizliği olan çocuklara yönelik eğitim ortamları ve eğitimlerinde kullanılan iletişim yaklaşımları. Işsitme ve görme yetersizliği $(\mathrm{H}$. Gürgür, \& P. Şafak, Eds.). Pegem Akademi.

Gol Guven, M. (2016). A study on developing educational material which supports the Turkish Sign Language acquisition (TID) of the children with hearing impairment. Turkish Sign Language studies (E. Arrk, Ed.). Koc University Publications. 
Hopper, B. (2001). The role of the HEI tutor in initial teacher education school-based placements, Mentoring and Tutoring, 9(3), 211-222. https://doi.org/10.1080/13611260120111996.

https://www.meb.gov.tr/meb_iys_dosyalar/2020_05/01152722_MEBMakale.pdf.

İlkbasaran, D. (2016). Studying in terms of young people's communication habits deaf and sociolinguistics of Turkish Sign Language in Turkey. Turkish Sign Language studies (E. Arık, Ed.). Koç University Publications.

Kemaloğlu, Y. (2016). Türkiye'de sağırlığın görünürlüğü ve toplumsal ve eğitsel sorunları üzerine demografik bir inceleme. Ellerle konuşmak Türk İşaret Dili araştırmaları (E. Arık, Ed.). Koç Üniversitesi Yayınları.

Kirazlı, G. (2020). İşitme kaybı. İşitme yetersizliği ve görme yetersizliği olan çocuklar ve eğitimleri (P. Piştav Akmeşe, \& B. Altunay, Eds.). Nobel Yayıncılık.

Kubus, O. Ilkbasaran, I., \& Gilchrist S.K. (2016). Sign language in Turkey planning and legal status of Turkish Sign Language. Turkish Sign Language studies (E. Arık, Ed.). Koç University Publications.

Louws, M.L., van Veen, K; Meirink, J.A. \& van Driel, J.H (2017) Teachers' professional learning goals in relation to teaching experience, European Journal of Teacher Education, 40(4), 487504, https://doi.org/10.1080/02619768.2017.1342241.

Mann,W.,Haug,T., Kollien, S., \& Quinto-Pozos,D. (2015). Teaching signed languages. The Encyclopedia of Applied Linguistics (C.A. Chapelle, Ed.). Wiley. https://doi.org/10.1002/9781405198431.wbeal1436.

MEB (2011, Hazinran 21, 2020) Türkiye Eğitim İstatistikleri-Örgün Ĕ̌̆itim. 2010-2011. http://sgb.meb.gov.tr/meb_iys_dosyalar/2012_12/06021014_meb_istatistikleri_orgun_egiti m_2010_2011.pdf.

MEB (2016, Haziran 21, 2020). Özel eğitim ve rehberlik hizmetleri genel müdürlüğü,Türk işaret dili dersi programi. http://orgm.meb.gov.tr/www/turk-isaret-dili-dersi-ogretim-programiyururlukte/icerik/766.

MEB (2018). Millî Ĕ̈itim İstatistikleri örgün eğitim (National Education Statistics formal education 2017/'18).

http://sgb.meb.gov.tr/meb_iys_dosyalar/2018_09/06123056_meb_istatistikleri_orgun_egiti m_2017_2018.pdf.

MEB (2018, Haziran 19, 2020). Özel ĕgitim hizmetleri yönetmeliği, https://www.resmigazete.gov.tr/eskiler/2018/07/20180707-8.htm.

MEB (2019). Millî Ĕğitim İstatistikleri örgün eğitim (National Education Statistics formal education 2018/'19).

http://sgb.meb.gov.tr/meb_iys_dosyalar/2019_09/30102730_meb_istatistikleri_orgun_egiti m_2018_2019.pdf.

MEV (Milli Eğitim Vakfı, 1994, Haziran 17, 2020) Türk millî eğitim sisteminin yasal dayanakları https://www.mev.org.tr/images/kitapciklar/yasaldayanaklar.pdf.

Miles, M. B., \& Huberman. M. (1994). Qualitative data analysis: An expanded sourcebook. Sage Publishers.

National Deaf Children's Society (NDCS) (2020, June 16). COVID-19 (coronavirus):support for deaf children, https://www.ndcs.org.uk/covid-19-coronavirus-support-for-deaf-children/ 
Odluyurt, S., \& Batu, E.S. (2014). Kaynaştırmanın başarısını etkileyen faktörler. Özel gereksinimli çocukların kaynaştırılması (E.S. Batu, A. Çolak, \& S. Odluyurt, Eds.). Vize Yayıncılık.

Piştav Akmeşe, P. (2015). Türk İşaret Dili (TİD) eğitimi ve yükseköğretim programlarında işaret dili dersi. Ahi Evran Üniversitesi Kırşsehir Eğitim Fakültesi Dergisi (KEFAD). 17(3), 341-361.

Piştav Akmeşe P. (2018). İşitme yetersizliği olan öğrenciler. Özel eğitim ve Kaynaştırma (Ü. Şahbaz, Ed.). Anı Yayıncılık.

Piştav Akmeşe P. (2020). İşitme yetersizliği olan çocukların gelişimsel özellikleri ve kullandıkları iletişim yaklaşımları. Işsitme yetersizliği ve görme yetersizliği olan çocuklar ve eğitimleri (P. Piştav Akmeşe, \& B. Altunay, Eds). Nobel Akademik Yayıncılık.

Pistav Akmese P., \& Acarlar F. (2015). Using narrative to investigate language skills of children who are deaf and with hard of hearing. Educ Res Rev, 11, 1367-81. https://doi.org 10.5897/ERR2016.2865.

Piștav Akmeşe P. \& Kayhan N. (2016a). Okul Öncesi Düzeyde Eğitim Alan İșitme Engelli Öğrencilerin Eğitim Süreçlerinde Kullanılan İletişim Modlarına/Yaklaşımlarına İlişkin Öğretmen Görüşleri. Ege Eğitim Dergisi, 17(2), 296-332. https://doi.org/10.12984/egeefd.280747.

Piştav Akmeşe P., \& Kayhan N. (2016b). İşitme engelliler öğretmenleri ile odyoloji ve konuşma bozuklukları uzmanlarının işitme kayıplı çocukların eğitimi hakkındaki görüşleri. Mehmet Akif Ersoy Üniversitesi Eğitim Fakültesi Dergisi; 40, 88-112. https://doi.org 10.21764/efd.45205

Piştav Akmeşe, P., \& Kayhan, N (2017). İşaret Dili Dersine Katılan Öğretmen Adaylarının Görüşlerine Göre Türk İşaret Dili Eğitiminin İncelenmesi Turkish Online Journal of Qualitative Inquiry, 8(1), 1-38, https://doi.org 10.17569/tojqi.280054

Piştav Akmeşe, P., \& Kayhan, N. (2018a, March 29-31). Türk İşaret Dili dersini alan öğretmen adaylarının görüşlerine göre okul öncesi dönemde işaret dili öğretimi. 2 nd. International Congress on Early Childhood Intervention (ICECI2018) Bildiri Kitabı. 148-149,Antalya, Türkiye.

Piştav Akmeşe, P. \& Kayhan, N. (2018b, October 11-13). İşitme engelli bireylerin eğitiminde öğretimsel düzenlemeler ve Türk işaret dili kullanımı hakkında öğretmen görüşleri. 28. Ulusal Özel Ĕgitim Kongresi Tam Metin Bildiri Kitabı (Macit, Melekoğlu, Ed.). 148-156. Eskişehir, Türkiye.

Özer, M. (2020, June 19). Educational policy actions by the ministry of national education in the times of COVID-19. Kastamonu Education Journal, 28(3), 1124-1129. https://doi.org/10.24106/kefdergi.722280.

Sevinç, S. , Aslan, F., \& Özkan, B. (2013). İşitme engelli öğrenciler için öğretmen kılavuz kitabı. Milli Eğitim Bakanlığı Özel Eğitim ve Rehberlik Hizmetleri Genel Müdürlüğü. Milli Eğitim Basımevi.

Sucuoğlu, B., \& Kargın, T. (Eds.). (2006). İlköğretimde kaynaştırma uygulamaları. Yaklaşımlar, yöntemler ve teknikler. Morpa Yayınları.

Trittel M., Gerich M., Schmitz B. (2014). Training prospective teachers in educational diagnostics. Teachers' Professional development. the future of education research (S. Krolak-Schwerdt, S. Glock, \& M. Böhmer, Eds.). Sense Publishers. 
Townsend, T. (2011) Searching high and searching low, searching east and searching west: looking for trust in teacher education, Journal of Education for Teaching, 37(4), 483-499. https://doi.org/10.1080/02607476.2011.611017.

TBMM (1982, Haziran 19, 2020). Türkiye Büyük Millet Meclisi Türkiye Cumhuriyeti Anayasası 42. Madde II. Eğitim ve Öğrenim hakkl ve Ödevi. https://www.mevzuat.gov.tr/MevzuatMetin/1.5.2709.pdf.

Traxler, C. B. (2000). The Stanford Achievement Test 9th Edition: National norming and performance standarts for deaf and hard-of-hearing students. Journal of Deaf Studies and Deaf Education, 5(4), 337-348. https://doi.org/10.1093/deafed/5.4.337.

TÜIK-ÖSBA (2010, Haziran 21). Aile ve Sosyal Politiklar Bakanlığı ve Türkiye İstatistik Kurumu. TÜIK Yayınlarl. www.tuik.gov.tr/IcerikGetir.do?istab_id=244.

World Health Organization WHO (Dünya Sağlık Orgütü) (2020a, Haziran 18). Deafness and hearing loss. https://www.who.int/news-room/fact-sheets/detail/deafness-and-hearing-loss.

World Health Organization WHO (Dünya Sağlık Orgütü) (2020b, Haziran 19). Q\&A on coronaviruses (COVID-19). https://www.who.int/emergencies/diseases/novel-coronavirus2019/question-and-answers-hub/q-a-detail/q-a-coronaviruses.

World Federation of the Deaf (Dünya Sağırlar Federasyonu) (2020b, Haziran 20). Covid-19. http://wfdeaf.org/coronavirus/

Yıldırım, A., \& Şimşek, H. (2008). Sosyal bilimlerde nitel araştırma yöntemleri.7. Baskı-Seçkin Yayıncilik.

YÖK (2020a, Haziran 18). Pandemi Günlerinde Türk Yükseköğretim. https://covid19.yok.gov.tr/Sayfalar/HaberDuyuru/pandemi-gunlerinde-turkyuksekogretimi.aspx.

YÖK (2020b, Haziran 21). Yükseköğretim Covid-19 Bilgilendirme. https://covid19.yok.gov.tr/AnaSayfa. 